\title{
Fængsel på livstid
}

\section{To foredrag om løsladelse af livstidsfanger ${ }^{1}$ )}

\section{Af fængselspræst ERIK HINDSE-NIELSEN.}

Det er en stor glæde for mig overfor dette forum at få lov til at fremføre nogle tanker, som jeg længe har haft på hjerte. Når jeg bruger udtrykket, at det gælder noget, jeg ,har på hjerte“, har jeg dermed på forhånd villet tilkendegive, at tilhørerne ikke må vente sig teoretiske udviklinger eller rationelt begrundede påstande eller statistiske beregninger. Jeg kommer med det, som det springer frem af et gammelt fængselspræstehjerte, men det er mit håb, at det må fremgå af diskussionen, at hjertets grunde $o g$ forstandens grunde $\mathrm{i}$ den foreliggende sag vil vise sig at kunne forenes.

I straffelovens $\S 33$ hedder det: „Fængsel id $\phi$ mmes på livstid eller på tid, ikke under 30 dage og ikke over 16 år". Bag disse lakoniske ord åbner sig udsigt til to vidt adskilte kategorier af strafafsonere, ja, man kan sige: to helt forskellige verdener.

Først et par ord om fanger med tidsbestemt straf. Når en straffesag er sluttet med id $\phi$ mmelse af tidsbestemt fængselsstraf, vil det altoverskyggende sp $\varnothing$ rgsmål for den domfældte normalt være dette: Hvornår kommer jeg ud? I de fleste tilfælde ligger det fra begyndelsen nogenlunde fast, hvornår løsladelsen kan forventes, eventuelt på pr $\phi v e, o g$ under alle omstændigheder kendes den dato, som er den yderste grænse for frihedsber $\varnothing$ velsens varighed, det gælder også såkaldt ,,straf på ubestemt tid“.

Det må anses som et symptom på noget usundt, hvis dette spørgsmål er fangen ligegyldigt, også når der er tale om en forbrydelse af alvorligste karakter. Fangens håb om at genvinde friheden kan fuldtud forenes med ærlig anger og vilje til at bære sin straf.

Det ses undertiden, at man hæfter prædikatet: benådningsoptaget på en mand for at antyde, at han er uden forståelse overfor straffen. Det skal indrømmes, at benådningsoptagethed kan virke utiltalende og være udtryk for en negativ indstilling; men som helhed må det betragtes som et sundhedstegn, at en domfældt, som måske tilmed har nogle kære, han længes efter, og som venter på ham, beskæftiger sine tanker ikke blot med den normale løsladelse, men også med muligheden for på et tidligere tidspunkt at opnå afkortning i straffen. Noget andet er, at en ansvarsbevidst fængselsmand vil veje sine ord på guldvægt, hvis samtaler med fanger kommer ind på dette emne; men det er min over-

1) Foredragene er holdt i Dansk kriminologisk Selskab den 22. oktober 1958. — Referat i dagspressen frabedes. 
bevisning, at fængslets arbejde på enhver human måde - uden utidige benådningsdrøftelser — skal medvirke til at stimulere fangens frihedslængsel og hjælpe ham til at have noget at se frem imod. I modsat fald vil fængselsopholdet let komme til at virke sløvende og nedbrydende. Jeg vil endda mene, at man handler forkert ved at bestyrke en fange med relativ kort straf $i$ at vagre sig ved at modtage et tilbud om indstilling til pr $\varnothing$ vel $\varnothing$ sladelse med den motivering, at den opnåede ringe afkortning står i misforhold til prøvetidens længde og afhængigheden af et tilsyn. Friheden b $\varnothing \mathbf{r}$ af et sundt menneske vurderes så $h \varnothing j t$, at tabet af blot een dags frihed skal betragtes som en alvorlig sag.

(I en parentes kan jeg ikke lade være at tilføje, at det forekommer mig at være en alvorlig fejl $\mathrm{i}$ dansk lovgivning og retspraksis, at en bøde for en ubetydelig forseelse eventuelt kan omsættes til frihedsstraf.

Det samme gælder det her i landet endnu rådende forhold, at af soning af disciplinærstraffe, som idømmes en strafafsoner, selv for mindre alvorlige ting, ikke includeres i den ved domstolene id $\phi$ mte straffetid. Jeg ser ikke rettere, end at den slags medvirker til både for de straffede og hos myndighederne at devaluere synet på et af de største og helligste livsgoder: friheden).

Hvis man specielt samler tankerne om fanger med langtidsstraffe, d. v. s. fra 8-16 år, ligger sagen noget anderledes. For at et sådant menneske skal kunne bære indespærringen, og se medfanger komme og gå uden selv at gå i stykker på det, må han hjælpes til indtil videre at skubbe alle løsladelsestanker i baggrunden. I de første år må fængslet se det som sin opgave at hjælpe fangen til at forsone sig med sin skæbne og først på det psykologisk og administrativt rigtige tidspunkt begynde nærmere dr $\phi$ ftelser af fremtiden.

Det problem, vi skal behandle, drejer sig om løsladelse af fanger, som er id $\varnothing \mathrm{mt}$ frngselsstraf på livstid. Med livstidsfangen befinder vi os - som allerede sagt - i en verden helt for sig.

I det $\varnothing$ jeblik dommen: fængsel på livstid, falder, sænker håbløshedens totale mørke sig over den domfældte. Hvis han er et menneske med et nogenlunde normalt f $\varnothing$ lelsesliv, vil han måske allerede $\mathrm{f} \phi \mathrm{r}$ domfældelsen have været inde på tanker om, at livet er slut for hans vedkommende; han har ikke mere at leve for og se frem til. Det bedste ville være at $d \phi$. Selvom han skulle kende straffelovens $\S 37$, stk. II, vil det ikke føles som noget lyspunkt, snarere tværtimod. Der står: „,Fanger, hvis straffetid udgør 8 år eller derover, kan, når halvdelen af straffetiden, dog mindst 5 år, er forløbet, efter indstilling af anstaltens styrelse af Fængselsnævnet overflyttes til forvaringsanstalt for resten af deres straffetid. For livstidsfangers vedkommende kan sådan overflytning finde sted efter 16 års forl $\phi b^{\prime \prime}$.

Denne håbforladte tilstand varer dog ikke ved. Kortere eller 
længere tid efter, at afsoningen er begyndt, ser man som regel vedkommendes hele sindstilstand og indstilling til livet ændre sig. Når han er kommet ind i fæengselslivets rytme, har fået kontakt med nogle mennesker, er blevet sat $\mathrm{i}$ gang med rigtigt arbejde o. s. v., da kommer den dag, da han igen drister sig til at se fremad.

Det er klart, at denne ændring i livstidsfangens indre situation må bedømmes som noget positivt og som noget, man fra fængslets side må søge at bygge videre på. Men det er ligeså klart, at man kan komme til at gøre ubodelig fortræd og bevirke skæbnesvangre tilbageslag, hvis man på et for tidligt tidspunkt går ind på at dr $\phi$ fte l $\phi$ sladelsesmuligheder med livstidsfangen.

Spфrgsmålet er: Hvornår t $\phi \mathbf{r}$ man begynde?

På dette punkt foler fængselsmanden sig $i$ den grad på usikker grund, at han længe - meget længe - vil være utilb $\varnothing j e l i g$ til at indlade sig på fremtidsdr $\phi$ ftelser, som kan vække urealistiske forventninger hos fangen. Hvis denne selv tager initiativet til en sådan samtale, er man yderst forbeholden og forsigtig i sine udtalelser. Man vil så n $\phi$ dig risikere at for $\varnothing$ ge den sum af kummer, man sidder overfor ved at udtale en letsindig optimisme. Den samme varsomhed må man iagttage overfor livstidsfangens familie. Gennem det $\mathrm{f} \phi \mathrm{r}$ ste lange åremål er det ikke vanskeligt at finde ud af, hvad man skal sige, — blot man gør det på den rette måde. Man må ganske simpelt tilråde dem forel $\phi$ big at spekulere så lidt som muligt på den side af sagen. Hvad mennesker kan præstere af tålmodighed, når de føler sig under n $\varnothing$ dvendighedens lov, er ofte helt ufatteligt. Men $f \phi r$ eller senere indtræffer det tidspunkt, da livsmodet og længslerne og håbet vågner med styrke hos livstidsfangen og hans pårørende. Det kan være begyndelsen til en sund og god udvikling, under hvilken fangen holder sig fysisk og åndeligt i form, f $\varnothing$ lger med i tidens r $\not$ relser, holder sig orienteret om omverdenens begivenheder og længes efter kontakt med livet udenfor. Da kan det være svært at skulle svare forsigtigt og undvigende, når fangen og hans nærmeste kære betror en deres dybeste hjerteanliggender, og man selv af sin inderste overbevisning f $\varnothing l \mathrm{ler}$, at tiden egentlig er moden til at tage åbent og praktisk fat på en planlægning af fremtiden.

Livstidsfangerne kan groft inddeles i tre grupper.

1. Fanger, som har begåct en bestialsk forbrydelse og vedblivende må anses for farlige. Erfaringsmæssigt er det kun et fåtal, der kan henf $\varnothing$ res hertil. Næppe nogen myndighed t $\varnothing \mathbf{r}$ tage ansvaret for en sådan livstidsfanges frigivelse. ${ }^{2}$ ) Men hvad da?

På et ret tidligt tidspunkt vil det erfarne fængselspersonale kunne udpege fanger, hørende til denne kategori. Hvis der med

2) Med mindre den pågældende $\mathrm{i}$ tidens $1 \varnothing \mathrm{b}$ fuldstændigt forandrer sig, en mulighed, som naturligvis aldrig på forhånd kan udelukkes. 
tilslutning fra de på dette område særlig sagkyndige er enighed om, at en sådan fange må anses for farlig på grund af mental defekt, bør der ikke hengå længere tid, end en observation kræver, f $\varnothing \mathrm{r}$ han tages ud af det almindelige fængsel, hvor hans tilstedeværelse kan betyde en uhyre belastning for det $\phi$ vrige arbejde, og overflyttes til en sikringsafdeling med helt andre behandlingsformer og med den for en sådan afdeling særegne hospitalsatmosphære.

2. Gruppe 2 omfatter fanger, som efter at være dømt for en oprørende forbrydelse har udvist tilfredsstillende forhold under lang tids fængselsophold, men hvis prognose man står skeptisk overfor, dels fordi man på grund af deres ringe forståelse og erkendelse, deres afstumpede følelsesliv og dybe karakterbrist ikke $t \varnothing r$ se bort fra muligheden af nye, alvorlige forbrydelser, dels fordi de ingen nære pårørende har at støtte sig til og bl. a. derfor vil være vanskeligt stillet ved en løsladelse med fare for ikke at kunne glide ind $\mathrm{i}$ en normal social tilværelse.

For denne gruppes vedkommende vil spørgsmålet om eventuel pr $\varnothing$ vel $\varnothing$ sladelse formentlig ikke blive aktuelt f $\phi$ r efter ca. $13-16$ års forl $\varnothing$ b. Efter mit sk $\phi \mathbf{n} b \phi r$ sådanne fanger (forudsat at deres farlighed ikke sk $\phi$ nnes at være til hinder derfor) omkring 10 år efter indsættelsen fors $\emptyset$ ges overflyttet til halvåbent fængsel, dels som en human foranstaltning, dels for at se, hvordan de klarer sig under friere forhold, dels endelig for at formidle overgangen til de helt frie forhold ved eventuel senere løsladelse på pr $\varnothing$ ve.

Jeg er ganske klar over, at der knytter sig en så stor alvor til disse menneskers skæbne indenfor de to nævnte grupper, at deres problemer med rette kunne kræve en virkelig indgående behandling ved diskussionen her i, aften. Men for at koncentrere interessen om det, som ved denne lejlighed ligger mig så ganske særligt på sinde, har jeg indskrænket mig til disse antydninger. Af samme grund forbigår jeg også de dermed mere eller mindre nært beslægtede problemer vedrørende løsladelse af sikkerhedsforvarede og psykopatforvarede.

3. Vi kan nu gå over til gruppe 3 , til hvilken henregnes fanger, der ikke af natur er kriminelle, men som i en desperat situation er blevet drabsmænd under omstændigheder, der kvalificerer til den strengeste straf, vor straffelov hjemler, altså fanger, om hvem man mener at turde antage, at de ikke fremtidig repræsenterer nogen fare for retssikkerheden.

Man kan indenfor denne gruppe finde sæerdeles sympatiske mennesker. Jeg t $\phi \mathbf{r}$ sige, at jeg blandt disse folk har truffet enkelte, som jeg vil kalde adle mennesker med en retsindig tankegang, og som har båret deres straf gennem de mange år på en så vardig måde, at man kun kan nære medmenneskelig agtelse for dem.

Hertil kommer måske, at det drejer sig om en familiefader, hvis hustru og børn ikke alene har bevaret kærligheden til deres „far", 
men som gennem den frelles ulykke og adskillelse - paradoksalt nok - er kommet hinanden nærmere end nogensinde f $\phi \mathbf{r}$. De derhjemme venter trofast.

Jeg har et konkret tilfælde i tankerne: Manden var sidst i trediverne, da han begik det drab, for hvilket han id $\phi$ mtes livsvarigt fængsel. Han eneste s $\phi$ n var dengang endnu ukonfirmeret. Nu er han voksen og gift, og faderen nærmer sig de 50. Igennem en halv snes år har denne familie på den smukkeste måde holdt sammen under adskillelsen og båret sin bitre og uvisse skæbne med værdighed og sjælsstyrke. Men har de noget at se frem til? Og kan de holde ud? Hvornår tør man begynde at tale åbent med dem om sagerne?

Selv stiller disse mennesker ikke spфrgsmål, hverken fangen eller hustruen eller sønnen. Men hvad har samfundet at sige til de tavse spфrgsmål, vi alligevel her står overfor?

Hvis det drejede sig om en 16 års dom, ville fangen allerede efter 8 års forl $\varnothing$ b kunne indstilles til pr $\varnothing$ vel $\phi$ sladelse efter straffelovens $\S 38$, stk. III, og under alle omstændigheder ville han og hans familie have et reelt og berettiget håb om at kunne se frem til et nyt liv i fællesskab, når 10 år 8 mdr. er afsonet, jfr. $\S 38$, stk. I.

Men nu drejer det sig altså om en livtidsfange: engang forsidestof $i$ alle blade, brændemærket af den offentlige mening og skildret som et udyr, d $\phi \mathrm{mt}$ af den offentlige retfærdighed, derpå forsvundet i den store maskine, glemt af offentligheden, kun husket af dem, hans gerning ramte direkte og indirekte. Og så af dem, der nu udg $\phi \mathrm{r}$ hans daglige omgang i ulykken. Her ses det, hvilket svælg der åbner sig mellem den tidsbestemte straf og straffen på livstid.

Overfor den sidste kategori af fanger og deres familie står man underlig magtesl $\phi$ s og må indskrænke sig til at holde afsoningen gående og få det hele til at forl $\varnothing$ be så godt som muligt. Men - kan samfundet virkelig slå sin samvittighed til ro med, at dommen jo lyder på fængsel på livstid, så at spørgsmålet om eventuel løsladelse ligger i et helt andet plan, end hvis det havde drejet sig om en dom på 16 år?

Straffens hovedformal er fangens sociale genrejsning. Hvis man må lade denne betragtning gælde også for nogle af de fanger, hvis dom rent bogstavelig lyder på fængsel på livstid, melder det spørgsmål sig: Hvor længe kan et menneske afsone straf indenfor et lukket statsfængsels rammer, f $\phi$ rend indespærringens nedbrydende f $\varnothing$ lger melder sig? Det er et vanskeligt spørgsmål at besvare, men erfaringen taler for, at grænsen ligger omkring 10 år.

Hvis dette er rigtigt, melder det påtrængende spørgsmål sig, om der ikke kan tilvejebringes mulighed for, at fanger, der efter fængslets enstemmige bed $\phi$ mmelse henhører under gruppe III, 
administrativt ligestilles med og behandles på linie med dem, der er dømt til 16 års fængsel, uden at dette beh $\phi$ ver at medf $\phi r e$ forstemmende kompetencestrid mellem domsmyndighederne og administrationen?

Mine tanker går i al enkelhed i den retning, at når en sådan fange har afsonet ca. 10 år, skulle fængslet frit kunne begynde at drøfte fremtiden både med ham og hans pårørende, med udtrykkelig betoning af, at de ikke må forvente nogen nær forestående 1 $\phi$ sladelse. Samtidig skal der så at sige automatisk ske indberetning til Direktoratet for Fængselsvæsenet med udf $\phi r$ lig redeg $\varnothing$ relse for fangens forhold gennem de forl $\varnothing$ bne 10 år og for hans fremtidsplaner, vedlagt erklæringer bl. a. fra anstaltens specialister i psykiatri og psykologi. Det kan samtidig overvejes, hvorvidt det vil være hensigtsmæssigt på dette tidspunkt at overføre fangen til et åbent fængsel; dette $b \phi r$ dog ikke finde sted imod fangens eget $\varnothing$ nske, og det må for alt i verden ikke blive noget $i$ retning af en narresut, som fører sagen endnu mere ud i det uvisse.

Eet år efter den nævnte indberetning skal anstalten (eller den åbne afdeling, til hvilken fangen måtte være overf $\phi r t)$ indsende en supplerende redeg $\varnothing$ relse, dels for fangens forhold i det sidst

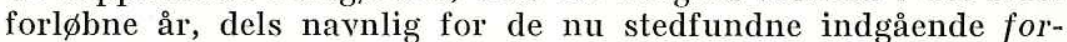
sorgsmæssige unders $\varnothing$ gelser og forhandlinger, som skulle kunne give et afsluttende billede af de forhold og muligheder, fangen har at gå ud til. På det således foreliggende grundlag træffer justitsministeriet bestemmelse om eventuelt at indstille fangen til benådning på nærmere fastsatte vilkår på linie med almindelig pr $\phi v e l \phi s l a d e l s e s p r a k s i s$.

Blandt de indvendinger, der kan tænkes fremf $\phi \mathbf{r t}$, skal jeg n $\varnothing$ jes med at foregribe een: Den, der ligger $\mathrm{i}$ hensynet til den myrdedes efterladte. Man vil sige, at hensynet til den dræbtes pårørende må veje stærkere end hensynet til fangens.

Det er naturligvis smukt og rigtigt, at samfundet f $\varnothing$ ler ansvar overfor en familie, der har varet ude for den tragedie, at den har mistet sin forsørger ved en forbrydelse. Men forhåbentlig vil det være muligt for samfundet at opfylde sådanne forpligtelser på en nyttigere og bedre måde end blot ved at drage omsorg for, at der påf $\phi$ res gerningsmanden og hans familie un $\phi$ dig store lidelser ved, at han holdes indespærret $\mathrm{i}$ væsentlig længere tid, end det efter alle sagkyndiges sk $\phi n$ (der kender manden, således som han er nu!) i hvert enkelt tilfælde må anses for hensigtsmæssigt. Jeg er overbevist om, at hvis spørgsmålet om, hvorvidt en drabsmand af den under gruppe III skildrede type kunne løslades efter ca. en halv snes års forl $\phi b$, blev forelagt of rets eferladte, ville de i mange tilfælde sige i fuld oprigtighed, at „for vor skyld skal han ikke sidde i fængsel længere".

Det har været min hensigt med disse lægmandsbetragtninger 
at røre ved et problem, som trænger sig stærkt på for enhver, der har sin daglige gang et sted, hvor der opholder sig livstidsfanger.

Når de kompetente myndigheder skal træffe den endelige afgørelse i spørgsmålet om eventuel løsladelse af en livstidsfange, er det mit håb for den kommende tid, at de til anstalterne nu knyttede specialister i psykiatri og psykologi, som er blandt dem, der har et personligt kendskab til fangen, må kunne bidrage til at give indstillingerne også vedr $\phi$ rende livstidsfanger en sådan vægt, at specialpræventive hensyn i hvert fald vurderes lige med generalpræventive; trods alle store, glæedelige fremskridt i de sidste årtier, er dette et mål, som endnu slet ikke er nået.

Erik Hindse-Nielsen.

II. Af vicedirekt $\phi \mathrm{r}$ i direktoratet for fængselsvæsenet

\section{AXEL HYE-KNUDSEN.}

Fængsel på livstid er straffelovens strengeste reaktion. Denne straf er hjemlet for alvorlige statsforbrydelser, farlig brandstiftelse, voldtægt under særdeles skærpende omstændigheder og manddrab.

I tiden fra den nye straffelovs ikrafttræeden og til nu er der ialt d $\varnothing \mathrm{mt} 45$ personer til fængsel på livstid. Der ses her bort fra domme afsagt over personer, der tillige er d $\phi \mathrm{mt}$ efter straffelovstillægget af 1 . juni 1945 . Heraf er 11 blevet l $\phi$ sladt, og 1 fange har begået selvmord en god måneds tid efter hensættelsen i statsfængslet.

Der dømmes årligt 1 à 2 til fængsel på livtid. I nogle år har der dog ingen domfældelser været, således i 1934, 42, 44, 45, 53 og 1956, og i nogle år har tallet varet oppe på 4-5, således i 1935 i 47 og 49 .

Der er i dag 33 afsonere i vore statsfængsler, d $\phi \mathrm{mt}$ til fængsel på livstid. Alle 33 er d $\varnothing \mathrm{mt}$ for manddrab, nogle af dem i forbindelse med voldtægt, r $\varnothing$ veri og andre alvorlige forbrydelser. Af de 33 har 15 hensiddet $\mathrm{i}$ over 10 år, medens 18 endnu ikke har afsonet 10 år.

Af livstidsfanger, der har været indsat siden 1903, og som er l $\phi$ sladt indtil 1953, har 33 fanger ialt afsonet 517 år eller gennemsnitligt 15,7 år. Mediantallet er 15, d. v. s. at halvdelen har afsonet mindre og halvdelen mere end 15 år. For perioden 1903 til 1944 har 16 fanger afsonet 242 år; det giver et gennemsnit på 15,2 år, og af dem, der er løsladt fra 1945 til 1953, har 17 fanger afsonet 175 år, d. v. s. 16,2 år i gennemsnit. Siden 1953 er der ikke l $\varnothing$ sladt fanger, der har været id $\phi \mathrm{mt}$ fængsel på livstid. Af de 33 fanger har 1 afsonet 8 år, $1-9$ år, $4-10$ år, $2-12$ år, $4-13$ år, $4-14$ år, 3 - 15 år, $4-16$ år, $1-18$ år, $3-19$ år, $1-20$ år, $2-21$ år, 1 - 23 år, 1 - 26 år og $1-33$ år. 
Den, der blev løsladt tidligst, var en kvinde, der i december 1942 med et jagtgevær havde skudt en kvinde, til hvis mand hun gennem år havde stået i k $\phi$ nsligt forhold, og den pågældende kvinde afgik ved d $\varnothing$ den efter nogle dages forl $\varnothing \mathbf{b}$ som f $\varnothing$ lge af sine skudsår. Der var det særlige ved denne benådningssag, at hendes s $\varnothing \mathrm{n}$ på grund af blodsygdom havde fået amputeret begge ben og var fuldstændig afhængig af andres hjælp, hvorfor det ville være af uvurderlig betydning for ham, om moderen kunne blive l $\phi$ sladt og give ham den nødvendige pleje. Det siger sig selv, at hendes forhold i fængslet havde været eksemplariske, og man f $\varnothing$ lte sig overbevist om, at hun ingensinde påny ville begå noget strafbart, og det har da også holdt stik.

Den fange, der har siddet i 23 år, var dømt for grov uterlig behandling af 8 -års pige, som han umiddelbart derefter kvalte. Han blev løsladt i juni 1953, og siden den tid har man intet ufordelagtigt hørt om ham.

Den fange, der har siddet i 26 år, havde i 1923 dræbt en gift kvinde, med hvem han var kæreste. Når han blev holdt tilbage sålænge, stod det $\mathrm{i}$ forbindelse med vanskelighederne ved at få ham passende placeret. Han blev benådet og tilbragte de f $\varnothing$ rste 5 år efter løsladelsen på optagelseshjem. Derefter var der større vanskeligheder med at få ham placeret, og da han havde udvist uterligt forhold overfor nogle småpiger i København, blev der rejst sag på ham. Han blev mentalundersøgt, og det viste sig, at han led af en sindssygdom, og han blev indlagt på Sct. Hans, hvor han kort efter afgik ved døden.

Den fange, der har siddet længst — 33 år — var d $\phi m t$ for voldtægt overfor sin egen moder og derudover flere tilfælde af voldtægt og fors $\phi$ g herpå samt r $\phi$ veri. Når løsladelsen af ham trak så længe ud, stod det i forbindelse med, at moderen stadig var bange for ham, og det var først, da hun afgik ved d $\phi$ den, at man tog skridtet til $1 \phi$ sladelse.

Hvordan går det nu en 60-rig, der skal løslades efter 33 års hensidden?

Som vilkår for løsladelsen blev det fastsat, at han skulle tage ophold på et optagelseshjem. Her gik det meget godt den første tid, men det kunne dog mærkes, at han af og til længtes ,hjem“ til livet i Horsens. Et halvt år efter anbringelsen forlod han hjemmet, og forstanderen fik at vide, at han havde sagt, at han ville „hjem“ igen til Horsens. Han blev anholdt og sendt tilbage til optagelseshjemmet, hvor han var det første år. Derefter fik han en plads som altmuligmand $\mathrm{i}$ et sommerpensionat. Her var han godt tilfreds med at være, men pensionatet måtte lukke, og han var der derfor kun i 3 måneder. Derefter var han i mange skiftende pladser, og det var svært for ham at falde til ro. Han blev så anbragt i en slags familiepleje på en gård på Sjælland, og her var han et par år. Han fik kun en ringe $1 \phi n$, men han fik alders- 
rente, og så klarede han sig. Af og til havde han nogle vagabonderingsture, og han kunne være noget kværulerende og opfarende. Det krævede en meget energisk indsats fra den tilsynsf $\varnothing$ rende at klare ham gennem vanskelighederne, og han har opnået et så godt forhold til den løsladte, at forbindelsen fortsættes på frivillig basis.

Løsladte har i hele perioden ikke haft nærmere tilknytning til andre mennesker end den tilsynsf $\varnothing$ rende og hans familie, som han til stadighed vender tilbage til - i særdeleshed når han har bragt sig $\mathrm{i}$ en sằdan situation, at han overhovedet ikke har mulighed for selv at $l \varnothing$ se den.

Han har til stadighed været stærkt optaget af fortiden, og hans samtaleemner har næsten kun været om politi og fængselsophold. Hans vagabonderingstrang og manglende evne til at kunne falde til ro står sikkert i forbindelse med den meget lange indespærring, idet han gennem denne er kommet på afstand fra det virkelige liv - ikke mindst i den f $\phi r s t e$ del af afsoningstiden, da han ikke havde adgang til aviser og radio.

Hvordan er vore erfaringer med hensyn til losladte livstidsfangers recidiv.

Jeg har tidligere redegjort for problemerne omkring løsladelse af drabsforbrydere, ${ }^{1}$ ) og det fremgik heraf, at der i dette århundrede kun har været 1 tilfælde, hvor en person, der havde været id $\phi m$ t en livsvarig straf, påny havde gjort sig skyldig i mord. Det var en mand, der var dømt i 1905 til livsvarigt tugthus for voldtægt og drab af 19-årig tjenestepige. Han blev benådet i 1920 . I 1931 blev han i Canada d $\phi$ mt til d $\phi$ den og henrettet for mord.

Af andre tilfælde, hvor der overhovedet har været tale om kriminalitet begået af løsladte livstidsfanger, var der et tilfælde med en morder, der blev løsladt efter 15 år. Han begik ufarlige tyverier og fik en fællesstraf af fængsel i 6 måneder og 60 dage. Det andet tilfælde - det var en mand, der i 1950 blev benådet for en livstidsstraf, som var id $\phi \mathrm{mt}$ ham i maj 1936, og efter $1 \varnothing$ sladelsen havde han gjort sig skyldig i sædelighedsforbrydelse, for hvilken han fik straf af fængsel i 8 måneder. Han blev fritaget for at afsone resten af livstidsstraffen. Senere har der igen været sag på ham for uterlighed, og han blev i september 1957 d $\phi m t$ til anbringelse i psykopatforvaringsanstalt.

Som foran anf $\phi$ rt er der i dag 33, som afsoner fængsel på livstid, og af disse har 15 siddet mere end 10 år. Af de 15 har sp $\phi r g s-$ målet om løsladelse været rejst for de 10 . De 5 , som man ikke har beskæftiget sig med, er for det første en mand, som i 1928 blev id $\phi \mathrm{m}$ t tugthusarbejde i 16 år for at have dræbt en skovbetjent, der ville anholde ham for krybskytteri. Han blev benådet i maj 1937. Efter nogle måneders forl $\varnothing \mathbf{b}$ begik han nogle småtyverier og fik en straf af fangsel i 4 måneder og kom i forbindelse hermed til at afsone ca. halvdelen af reststraffen. Han blev

1) NTfK 1954 s. 115 og flg. 
løsladt i oktober 1941, og i januar 1943 blev han d $\phi$ mt til fængsel på livstid for manddrab, idet han i en plantage i Jylland havde dræbt en slagtermester, som han havde slået i hovedet med en granraft, hvorefter han tilegnede sig hans tegnebog, der indeholdt ca. $2.000 \mathrm{kr}$.

De andre 4, som er d $\phi \mathrm{mt}$ for særdeles alvorlige forbrydelser, har kun lige siddet lidt over 10 år.

Den, der har siddet længst, har siddet i 25 år, men er også dels idømt fængsel på livstid for drab og derefter i 1934 fængsel i 8 år for overfald på en fængselsbetjent. Når løssladelsen af ham er trukket så længe ud, skyldes det dels vanskeligheder ved at få ham prøvet på en åben afdeling, eventuelt optagelsesshjem, og senest konstateringen af, at han lider af en sygdom chorea huntington. Han er for tiden indlagt til observation.

Den næste er en morder, som har siddet indespærret siden 1935. Det er denne sag, som professor le Maire har omtalt i sit foredrag, holdt ved Dansk psykiatrisk selskabs fortsættelseskursus i juni 1950, og som er gengivet i Tidsskriftet 1951 ,Forvaring uden behandling“. ${ }^{2}$ ) Her beskrives tilfældet således: „Der var sket det, at en mand i en nattetime var brudt ind på en landejendom for at forskaffe sig samleje. Han havde været i k $\phi$ bstaden, hvor han havde drukket en del og var blevet påvirket af spiritus. Han ville have truffet en kvinde inde i byen, men da dette ikke lykkedes, gik han altså i aktion på en landejendom, han passerede på hjemvejen. Da han kom ind i stuehusets soveværelse, så han, at der lå 2 volksne og 1 barn, alle sovende. Han kunne ikke i mørket se, hvem der var manden og hvem kvinden, men troede, at den person, der var ham nærmest, var manden, hvorfor han rettede flere $\phi \mathrm{ksehug}$ imod denne person, der derved dræbtes. Det viste sig imidlertid, at det var gårdejerens hustru, han havde dræbt, og gårdejeren var nu imidlertid vågnet og satte sig til modværge“". Til trods for, at han blev karakteriseret som et arveligt belastet, stærkt psykopatisk præget individ med udtalte karakteriologiske og moralske brist, periodisk ganske uden hæmninger især overfor seksuelle impulser, og retslægerådet havde betegnet ham som uegnet til påvirkning gennem straf og anbefalet psykopatforvaring, blev han $d \phi m t$ til livsvarigt fængsel. Forklaringen var den, at fængselsdirektoratet til sagen havde udtalt, at forvaringsanstalten i Herstedvester ikke kunne anses for et egnet anbringelsessted for forbrydere af tiltaltes type, idet sådanne på grund af deres særlige farlighed faldt udenfor det system, man hidtil her havde praktiseret og ville beh $\phi$ ve en kvalitativt ganske anden behandling end den almindelige. Retslægerådet havde derefter udtalt, at man efter det foreliggende ikke skulle udtale sig imod, at den pågældende - uanset hans psykopati - id фmtes livsvarigt fængsel. Anklagemyndigheden, daværende rigsadvokat Goll, havde i tilknytning til sin supplerende foresp $\phi$ rgsel til rådet frem-

2) NTfK 1951 s. 21 og flg. 
draget som et særligt argument, at der her ville blive tale om livsvarigt fængsel, og at en sådan straf ikke kan siges at forudsætte, at den pågældende er påvirkelig af straf, men må betragtes som en af retssikkerhedshensyn motiveret varig uskadeligg $\varnothing$ relse.

Han kom altså ikke i psykopatforvaring, men blev afleveret til det almidelige fængsel og sad de første mange år i Horsens, hvor han dog en tid var anbragt på annekset i Amstrup. Hans forhold i Horsens har hele tiden været gode, han er i almindelighed rolig og høflig og nem at omgås, er dog noget indesluttet og reserveret og giver sjældent udtryk for, hvad der rører sig i ham. Han synes til tider at være noget stædig og trodsig, men er som regel nem at tale til rette. Han har været beskæftiget ved en betroet post ved landbruget og har passet denne særdeles tilfredsstillende og har aldrig svigtet den tillid, der er vist ham ved dette betroede arbejde, og forholdet til medfangerne har altid været godt. Han klarer sig tilsyneladende udmærket med den behandling, der kan gives ham i det almindelige fængsel, og psykiateren kommer f $\varnothing \mathbf{r}$ st ind i billedet, da der bliver spørgsmål om udskrivning.

I december 1950 afgiver fængselsvæsenets psykiatriske konsulent en erklæring om fangen, efter at han havde været indlagt på observationsafdelingen. Straks ved indlæggelsen hævdede han, at hvis der var tale om operation, så skulle han ikke nyde noget. Han undrer sig over, hvorfor man ikke vil lade ham gå ud nu, medens han endnu er arbejdsdygtig; hvis han skal vente en 3-4-5 år, er han bange for, at han blot er til socialhjælp, og det kan han ikke tænke sig, så må han hellere blive i anstalten. Erklæringens konklusion går ud på, at der ikke er opnået nogen antydning af tilslutning til en kastrationstanke. Han har ligesom på Amstrup vist sin arbejdsmæssige stabilitet, har psykisk været velafbalanceret, men gjort et noget stivsindet, nærmest stædigt indtryk. Endvidere udtales det, at der er ikle under observationen oplyst noget, der kan berettige til at gennemføre en kastration, og der foreligger intet bevis for, at han kan betegnes som seksuel abnorm. Benådningen blev afslået i 1951 og i 1954. I 1956 var spørgsmålet påny fremme, og den pågældende blev igen unders $\varnothing \mathrm{gt}$ af psykiater, som oplyste, at fangen har forklaret, at han stadig befinder sig godt. Han er fuldstændig rask både legemligt og sjæleligt, der er intet $\mathrm{i}$ vejen med hukommelsen, og hum $\phi$ ret er udmærket. Han mærker ikke noget til sin k $\phi$ nsdrift, og han f $\phi$ ler ingen seksuel trang. Den tidligere mindreværdsf $\phi$ lelse er nu forsvundet og afl $\varnothing$ st af selvtillid; fangen f $\phi$ ler sig overbevist om, at han nok skal klare sig, hvis han bliver løsladt. Han ønsker stadigvak ikke kastration, og konklusionen går ud på, at man vil ikke mene, at han længere frembyder nogen fare for retssikkerheden, heller ikke i seksuel henseende, og der er ingen psykiatrisk indikation for kastration.

Retslægerådet, som allerede i 1951 var gået ind for, at det ikke 
kunne anses for uforsvarligt, at han betinget benådedes mod at anbringes på optagelseshjem og senere under tilsyn anbringes i en egnet plads, har afgivet erklæring i 1956 og her udtalt, at domfældte efter det foreliggende er yderligere stabiliseret siden 1951. Der er fremdeles grund til at antage, at hans k $\phi$ nsdrift med årene er afsvækket. Som anført i rådets tidligere udtalelse er det vanskeligt at forudsige, hvorledes han efter 20 års fængselsophold vil kunne tilpasse sig til samfundet, men efter hvad der oplyses om hans arbejdsevne og tilpasningsevne indenfor fængslet, skulle udsigterne ikke være ringe, når han får støtte af tilsyn. Det må antages, at risikoen for farlige handlinger nu er meget ringe, og rådet anbefaler derfor benådning.

Anklagemyndigheden går imod, og præsidenten for landsretten er overvejende betænkelig ved på nærværende tidspunkt at anbefale benådning. Der gøres opmærksom på, at fangen, der på det tidspunkt var 56 år gammel og har nægtet at underkaste sig kastration, næppe kan antages endnu at være seksuel indifferent uanset hans udtalelser derom til den unders $\varnothing$ gende læge. Sp $\phi$ rgsmålet var fremme igen i 1957 på grundlag af et arbejdstilbud, der var fremskaffet, men anklagemyndigheden gik fortsat imod, og der blev givet afslag.

Hvorledes er forholdene i andre lande med hensyn til løsladelse af fanger dømt til fæengsel på livstid?

I England, hvor fængsel på livstid ikke er den strengeste straf, kan en livstidsfange løslades af The Secretary of State for Home Affairs når som helst i straffetiden. Det hedder i loven, at "the period to be served is described on the merit of each case."

I 10-året 1940 — 49 blev 80 mænd, som udstod fængsel på livstid, løsladt. 15 af dem afsonede 10 år eller mere, 44 blev løsladt imellem 7 og 9 år, og de resterende 21 blev løsladt efter 6 år eller mindre.

Efter belgisk ret kan en livstidsfange løslades på prøve efter 10 år, medens schweizisk ret sætter minimumstiden til 15 år.

I Sverige omsættes livstidsstraf i almindelighed ad benådningsvejen til 15 års strafarbejde, og det er en fast regel, at pr $\phi$ vel $\phi$ sladelse finder sted efter 10 års forl $\phi \mathrm{b}$.

I Norge er det fastsat, at den mindste fuldbyrdelsestid er 20 år, men denne bestemmelse er uden praktisk betydning. I tiden fra 1925 til 1940 blev der i Norge indsat 10 mænd til afsoning af fængsel på livstid. 1 af disse afgik ved døden under fængselsopholdet. Alle de $\varnothing$ vrige blev løsladt på prøve ved benådning på et langt tidligere tidspunkt end de 20 år. Den gennemsnitlige fuldbyrdelsestid for disse 9 fanger udgjorde 11 år og 7 måneder. Den i Norge ved kongelig resolution af 6 . april 1951 nedsatte kommité til at udrede spørgsmål om reformer i fængselsvæsenet, som afgav sin indstilling i 1956, har foreslået, at livstidsfanger skal 
kunne opnå pr $\varnothing$ vel $\varnothing$ sladelse efter udståelse af 10 års straffetid, $o g$ at slige sager skal afg $\varnothing$ res af Fengselsstyret. Lovbestemmelsen er foreslået formuleret således: Den, som er dømt til fængselsstraf på livstid, kan løslades på prøve, når han har udstået straf i mindst 10 år, og løsladelse af ham findes at være særlig begrundet.

\section{Manglerne ved den nuværende ordning.}

1) Der er for stor usikkerhed med hensyn til, hvornår spørgsmålet om benådning kan rejses. Det giver vanskeligheder for fangen, for fængselsfolkene, der skal tage sig af ham, og for de pårørende. Dette er der tilstrækkeligt redegjort for af pastor Hindse-Nielsen.

2) Usikkerheden spiller også ind med hensyn til de tilfælde, hvor man ville finde det $\phi$ nskeligt at kunne overflytte den pågældende til halvåben eller åben anstalt som overgang til en løsladelse. Det er ikke i alle tilfælde, at fangerne selv er interesseret i det, når de nu igennem en lang årrække har vænnet sig til forholdene i det lukkede fangsel, som jo også frembyder visse muligheder for arbejde i det fri. Betydningen af overflytning vil også afhænge af, hvilke muligheder man har med hensyn til anbringelse på åben anstalt. Det forudsatter i hvert fald, at forholdene på den åbne anstalt ikke ligger altfor meget under forholdene på den lukkede anstalt, navnlig med hensyn til muligheden for, at fangen kan få sit eget rum. Forhåbentlig lykkes det at få de åbne anstalter udbygget på en sådan måde, at de vil være egnede også til overflytning af livstidsfanger $i$ egnede tilfælde.

3) Det har vist sig uhensigtsmæssigt, at benådningsvejen skal benyttes ved løsladelse af livstidsfanger. Det medf $\phi r e r$ nemlig, at man ikke i tide tilstrækkeligt kan forberede løsladelsen, og man kan heller ikke give fangen tilstrækkelig tid til omstilling. Det er selvfølgelig noget, der kunne ændres uden lovændring.

4) Det kan navnlig udfra behandlingsmæssige synspunkter anf $\varnothing \mathrm{res}$, at tilbageholdelsestiden for livstidsfanger $\mathrm{i}$ visse tilfælde er for lang. Det er en almindelig erfaring, at livstidsfanger efter en halv snes år begynder at spekulere på mulighederne for benådning, og denne spænding og usikkerhed bevirker ofte, at de kommer i tilbagegang og ligesom går i stå, og man forpasser det optimale tidspunkt for løsladelsen.

Det er at håbe, at alle disse spørgsmål kan blive taget op i straffelovskommissionen, og hvis man kunne nå frem til en lovgivning på linie med det, der er foreslået i Norge, vil jeg tro, at man vil få et bedre instrument til behandlingen af disse sager. Man vil sikre sig, at sp $\phi$ rgsmålet bliver taget op og unders $\varnothing$ gt til en bestemt tid, og alle får mulighed for, at deres sag bliver unders $\emptyset \mathrm{gt}$. 
Jeg har foran nævnt professor le Maires foredrag „Forvaring uden behandling“. Det blev holdt i 1950, og en del har jo æendret sig i den mellemliggende tid. Jeg tror ikke, at det er helt retfærdigt at sige, at livstidsfangerne $\mathrm{i}$ det almindelige fængsel er underkastet forvaring uden behandling. Jeg tror heller ikke, at det er helt udt $\varnothing m m e n d e$ at sige, at livsvarigt fængsel er en af retssikkerhedshensyn motiveret varig uskadeligg $\phi$ relse. Den kan være det, men er det langtfra altid.

Hele galleriet eller så godt som hele galleriet af de personer, der omtales af le Maire, udg $\phi r$ en del af de personer, der er id $\phi \mathrm{mt}$ fængsel på livstid. Det er vist uden for al tvivl, at de må karakteriseres som psykopater, og at de fleste må henføres under straffelovens $\S 17$, men når man så ser, hvorledes det er gået under strafafsoningen, ser man, at $\mathrm{i}$ en hel del tilfælde er det gået udmærket, men der er også en del tilfælde, hvor der har været vanskeligheder, også vanskeligheder, der var så store, at de ikke kunne klares i det almindelige fængsel, men man har så måttet ty til assistance hos psykiateren. $\mathrm{Nu}$ er det heldigvis således, at man $\mathrm{i}$ alle anstalter under fængselsvæsenet kan få den forn $\varnothing$ dne psykiaterassistance, og hvis det drejer sig om tilfælde, der ikke kan behandles adækvat i den anstalt, hvor den pågældende sidder, kan der blive spørgsmål om overflytning til fængselsvæsenets psykiatriske observationsafdeling i Herstedvester. Der er flere, der for kortere eller længere tid har været overf $\varnothing$ rt til observationsafdelingen, og der er også flere, der har været overflyttet for kortere eller længere tid til sindssygehospital. I det første tilfælde, som le Maire nævnede, har der ikke under anstaltsopholdet været brug for psykiatrisk assistance det blev f $\phi$ rst n $\phi$ dvendigt, da sp $\phi$ rgsmålet om l $\phi$ sladelse skulle rejses. Det vil man jo lægge mærke til, at i de senere år er der ikke blevet nogen $1 \varnothing$ sladt fra livsvarigt fængsel, uden at der forinden har været erklæring fra psykiater og i mange tilfælde tillige fra retslægerådet, idet man har фnsket lægeautoriteternes bed $\phi \mathrm{m}$ melse af mandens farlighed.

De livstidsd $\varnothing$ mte er undergivet behandling, og det har da også vist sig, at der i mange tilfælde har fundet en betydelig udvikling sted.

Når man i sin tid har været meget betænkelig ved at anvende psykopatforvaring overfor kategorien af meget farlige drabsmænd, så stod det i forbindelse med det stade, psykopatanstalterne stod på straks efter ibrugtagelsen. Men når man tænker på den udbygning, der har fundet sted i Herstedvester, og på, at det har været n $\varnothing$ dvendigt at inddrage statsfængslet i Horsens til psykopatbehandling med en psykopatforvaringsanstalt og et psykopatfængsel, så er det et spørgsmål om det er rigtigt at anvende fængsel på livstid også i tilfælde, hvor den pågældende er henf $\phi$ rt til straffelovens $\S 17$, og straf findes uanvendelig. Ved dom 
til psykopatforvaring og anbringelse i psykopatforvaringsanstalten i Horsens kan den pågældende ikke blive anbragt i nogen mere sikker anstalt her i landet. De eneste betænkeligheder, der kan være forbundet hermed, er dels den mulighed, de psykopatforvarede har for udgangstilladelse, men det er jo en tilladelse, der skal godkendes af justitsministeriet, og i de tilfælde, vi her taler om, kunne der jo være anledning til at vente noget længere med udgangstilladelsen end $\mathrm{i}$ andre tilfælde. Den anden betænkelighed er spørgsmålet om udskrivning. Der er jo ikke fastsat grænser med hensyn til, hvornår dette spørgsmål kan rejses. Anstalten og de myndigheder, der i $\phi$ vrigt skal have med sagen at gøre, vil imidlertid ikke være i tvivl om, at der i sager af denne karakter skal hengå en betragtelig tid, inden man kan rejse $1 \varnothing$ sladelsesspørgsmålet. Skulle det blive rejst for tidligt af tilsynsværgen, vil det ikke medf $\phi r e$ st $\varnothing$ rre vanskeligheder at afsige en kendelse om, at den pågældende ikke for tiden kan løslades.

Der foreligger imidlertid et tilfælde, hvor en person, der har gjort sig skyldig i en straf, der kvalificerede ham til livsvarigt fængsel, er endt i psykopatforvaringsanstalten. Den pågældende blev ved dommen henf $\phi \mathrm{rt}$ under straffelovens $\S 16 \mathrm{og}$ d $\phi \mathrm{mt}$ til anbringelse på sindssygehospital. Efter nogle års forl $\varnothing \mathbf{b}$ viste det sig imidlertid, at han ikke var sindssyg, og spørgsmålet blev indbragt for retten igen, og retten traf nu bestemmelse om, at han skulle anbringes i psykopatforvaringsanstalt. Det drejede sig om en 21-årig tjenestekarl, der tjente hos en gårdejer på Randersegnen. Gårdejeren har senere forklaret, at der ikke havde været nogen konflikt mellem ham og karlen, men domfældte har gjort gældende, at han hadede gårdejeren, fordi denne aldrig talte til ham, og fordi maden ofte ikke var på bordet til tiden. Domfældte har endvidere forklaret, at han, den aften drabet fandt sted, havde bestemt sig til at skyde gårdejeren. Han ville stille sig på lur bag et træ, kort f $\phi r$ gårdejeren cyklede forbi, men han forpassede tiden og opgav denne plan. Om aftenen, i oktober 1945, sad han alene hjemme sammen med gårdejerens 11-årige datter og 15årige $s \varnothing n$. Datteren kom ind i stuen og bad domfældte lukke for radioen, da hun ikke ville høre på det spektakel. Domfældte svarede hertil, at hun kunne stoppe vat $\mathrm{i} \phi$ rerne, og pigen svarede, at det kunne hun gøre, men det ville karlen ikke kunne, da der ikke var vat nok. Hun hentydede herved til hans store $\varnothing$ rer. Domfældte vil hævde, at dette drilleri gjorde ham rasende, og at han efterhånden blev mere og mere fast besluttet på at ramme gårdejeren gennem at dræbe datteren. Drengen var faldet i s $\varnothing \mathbf{v n} i$ stuen, og domfældte gik ved halvtitiden ind på pigens værelse, hvor hun lå og sov, og kvalte hende med hænderne.

Hvordan går det så i psykopatforvaringen med hensyn til udskrivning?

I 1952 rejstes spørgsmålet på domfældtes foranledning af hans 
beskikkede tilsynsværge. Lægerne frarådede pr $\phi$ veudskrivning, uagtet hans opf $\phi$ rsel og arbejdsydelse i anstalten havde været upåklagelig, under hensyn til arten af hans kriminalitet med hele hans umodne og pubertetsprægede væremåde. Begæringen blev ikke taget til følge. I 1953 anmoder den pågældende om at blive overflyttet til sindssygehospital, fordi lægerne på psykopatanstal-

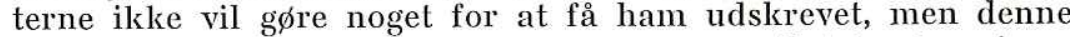
begæring blev også afvist. I 1955 var spфrgsmålet taget op igen, og retslægerådet udtalte, at den pågældende vel har forholdt sig rolig og vist god arbejdsflid, men nogen større ændring er dog ikke indtrådt $\mathrm{i}$ hans psykiske tilstand, og først for nylig har han villet indlade sig på en mere indgående psykologisk-psykiatrisk personlighedsbehandling, og rådet kan derfor ikke anbefale, at han udskrives på nuværende tidspunkt, og der træffes bestemmelse om, at udskrivningsbegæringen ikke kan tages til f $\phi$ lge. I 1956 var spфrgsmålet oppe igen. Fra anstaltens side oplystes det, at man i den forl $\varnothing$ bne tid yderligere har fået gennemarbejdet forvaredes lidt indesluttede og stive væeremåde, hans tendens til affektophobning og inadækvate reaktioner, og han har opnået en udmærket indsigt $i$ sine forhold. Hans affekter får nu mere adækvate afl $\phi \mathbf{b}$, ligesom hans tidligere tendens til dysforiske perioder helt er forsvundet. Han er blevet mere fri, virker umiddelbart venligere, mere smidig, aktiv og åben i sit væsen. I efteråret 55 har han fået rettet sine $\phi \mathrm{rer}$, som han ret hyppigt er blevet drillet med, og som muligvis også har været af betydning ved den nuværende kriminalitet. Begæringen blev ikke taget til følge.

Tilladelse til udgang fik han i september 1956.

I 1957 var spørgsmålet om udskrivning påny fremme. Retslægerådet anbefalede, at den forvarede blev udskrevet på pr $\varnothing v e$, således som man havde gjort det allerede i februar 1956. Anklagemyndigheden protesterede imod pr $\phi$ veudskrivning og har til st $\phi$ tte herfor gjort gældende, at det under hensyn til det begåede, meget alvorlige forhold må anses for nødvendigt, at den bedring, der synes i gang, iagttages endnu over et tidsrum. Retten var betænkelig og traf bestemmelse om, at udskrivningsbegæringen ikke for tiden kunne tages til f $\phi$ lge. Spфrgsmålet blev påkæret til h $\varnothing$ jesteret, der ved kendelse af 7. oktober 1957 stadfæstede lands-

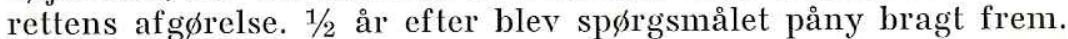
Fra anstalten var det oplyst, at man i den forl $\phi$ bne tid havde haft en række samtaler med forvarede, og han har herunder vist udmærket indsigt i de mekanismer hos ham, der tidligere har voldt vanskeligheder. Afslaget på prøveudskrivning har han også denne gang taget usædvanlig pænt og fornuftigt. Selvom han naturligvis gav udtryk for skuffelse, har det dog ikke bragt ham ud af den psykiske ligevægt, han nu gennem flere år har befundet sig i. Forvarede har haft et par udgange, som er forløbet helt tilfredsstillende. Han har god kontakt med familien, som han kor- 
responderer ret flittigt med, og hans forhold i anstalten er i $\phi \mathrm{v}-$ rigt helt tilfredsstillende. Retslægerådet udtalte, at den pågældende efter det oplyste er i fortsat god psykisk balance, ligesom han arbejdsmæssigt har klaret sig fuldt tilfredsstillende. At han har kunnet omgås funktionærer og medforvarede uden gnidninger må tillægges vægt, og rådet anbefaler prøveudskrivning. Anklagemyndigheden protesterede imod, at prøveudskrivning fandt sted på nærværende tidspunkt, og har til st $\varnothing$ tte herfor gjort gældende, at den meget alvorlige forbrydelse og den farlighed, man måtte tillægge domfældte på grund af de nærmere omstændigheder ved gerningen, må kræve, at der foreligger større sikkerhed for en karakterændring, end den der synes at foreligge. Ved kendelse af 21. april $1958 \mathrm{blev}$ der truffet bestemmelse om, at den pågældende skulle udskrives på prøve på nærmere angivne vilkår.

Her ser man, hvordan det kan gå med en person, der for alvorligt drab d $\phi$ mmes til psykopatforvaring. Der gik $12 \frac{1}{2} 2$ år fra den dag, han begik forbrydelsen og til den dag, han blev udskrevet.

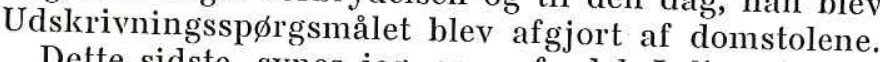

Dette sidste, synes jeg, er en fordel. I disse år, hvor man har gjort forskellige fremst $\varnothing \mathrm{d}$ for at begrænse den administrative frihedsber $\emptyset$ velse, ville det efter min mening kun være godt, om man også i disse tilfælde, hvor jeg godt ved, at der ikke foreligger administrativ frihedsberøvelse i teknisk forstand, men hvor det er spфrgsmål, om en indespærring skal udstrækkes på helt ubestemt tid, at dette afg $\varnothing$ res af domstolene i stedet for af en administrativ myndighed. Domstolene er indstillet på og vant til at træffe af gørelser af denne karakter, En interessant parallel har vi ved sikkerhedsforvaring. Her afg $\phi$ res efter straffelovens $\S 66$ spørgsmålet om $1 \varnothing$ sladelse på pr $\phi$ ve af det af specielle sagkyndige bestående fængselsnævn. Men når en person har hensiddet 20 år i sikkerhedsforvaring, skal han l $\emptyset$ slades, med mindre fængselsnævnet anser dette for betænkeligt. Spфrgsmålet om hans fortsatte forbliven i forvaringsanstalten forelægges da for lands-
retten.

Efter straffelovens $\S 37$, stk. 2, kan fængselsnæevnet efter indstilling fra anstaltens styrelse træffe bestemmelse om overflytning til sikkerhedsforvaringsanstalt af livstidsfanger, der har afsonet 16 år. Denne bestemmelse har været bragt $i$ anvendelse i et enkelt tilfælde i marts 1937.

Man kan vel heller ikke sige, at sikkerhedsforvaring har fået den anstaltsudbygning, som oprindelig var tænkt, og behandlingen er ikke så forskellig fra den almindelige frengselsbehandling, at der har været særlig interesse for en sådan overflytning. Det er imidlertid et spørgsmål, om bestemmelsen måske kunne få noget mere betydning, efter at sikkerhedsforvaringsanstalten nu huses i samme kompleks som psykopatforvaringsanstalten i
Horsens. 
For yngre fanger uden tidligere kriminalitet vil det dog være betænkeligt. Af de 33 livstidsfanger er $17 \mathrm{f} \phi \mathrm{dt} \mathrm{i}$ årene $1920-36$. Han, der var f $\phi$ dt i 1936, var 19 år ved domfældelsen og 20 år, da han blev indsat i Nyborg med fæengsel på livstid som sin første straf. (Han havde slået en 18-årig pige bevidstl $\varnothing$ s med en skruenøgle, voldtaget hende og derefter kvalt hende).

Overfor unge, der $\mathrm{i}$ en alder af $20-25$ år skal begynde afsoning af livstidsstraf, står fængslet overfor svære problemer. Først skal de sættes i gang, og så skal de holdes i gang. Een af dem gik i skomagerlære og fik svendebrev, men da dette var forbi, var der lang tid igen, inden han kunne håbe på løsladelse. Han påbegyndte så en ny lære i smedien, og han blev udlært, men stadig står løsladelsen ude $\mathrm{i}$ en ukendt fremtid. En anden, der inden indsættelsen var udlært som mekaniker, gik i lære som skrædder og blev udlært. Nogle af dem har vist en forbavsende trang til dygtigg $\phi$ relse, men det er vanskeligt at lægge den rette plan, som kan kulminere $\mathrm{i}$ en løsladelse, når det stiller sig helt uvist, hvornår en sådan kan gennemføres.

Sammenfattende vil jeg sige, at vi alle er klar over, at det er et meget alvorligt problem, vi beskæftiger os med, og at det er sager, hvor de generalpræventive hensyn har betydelig vægt, og hvor det er aldeles afg $\phi$ rende, at man ikke l $\phi$ ber nogen un $\phi$ dig risiko. Hensynet til samfundet går forud for hensynet til den fange, der så alvorligt har forbrudt sig, men når det er sagt, må man også tilf $\varnothing j e$, at når en livstidsfange skal løslades, b $\phi \mathrm{r}$ det ske på et tidspunkt, hvor han er egnet til løsladelse og ikke er slået i stykker for anden gang ved, at indespærringen er udstrakt udover hans bæreevne. Det er ikke min mening, at alle livstidsfanger skal ud efter 10 år — slet ikke. Hindse-Nielsens 3-deling stemmer med almindelig erfaring. Mange må sidde længere, men alle $b \phi r$ have deres sag forelagt for de kompetente myndigheder til bestemte tider. Får man $\S 17$-tilfældene udskilt og nogle d $\varnothing \mathrm{mt}$ til anbringelse i psykopatforvaringsanstalt, vil afgørelserne for de administrative myndigheder blive færre og enklere, og man vil også have nogen vejledning i de afg $\phi$ relser, der træffes af domstolene.

Det er ofte hævdet, at anbringelse i psykopatforvaringsanstalt giver mulighed for tidligere l $\varnothing$ sladelse end nogen anden foranstaltning. En sammenligning af, hvordan det går med hensyn til løsladelse af drabsmænd, der kommer i psykopatforvaring, og dem der får tidsbestemt fængsel, er meget vanskelig at foretage. Det eneste, der kan blive tilbage, da tilfældene er så forskellige, er en fornemmelse af, at man måske kommer lidt hurtigere ud ved dom til psykopatforvaring. ${ }^{3}$ ) Dette kan stå i forbindelse med,

3) 6 psykopatforvarede d $\varnothing \mathrm{mte}$ for drab er blevet pr $\phi$ veudskrevet efter henholdsvis $9,8,5 \frac{1}{4}, 5 \frac{1}{2}, 53 \%$ og $12 \frac{1}{2}$ år $-i$ gennemsnit $7 \frac{2}{3}$ år. 6 psykopatforvarede d $\varnothing$ mte for drabsfors $\phi g$ er blevet pr $\varnothing v e u d s k r e v e t$ efter henholdsvis $11 \frac{1}{2}, 7 \frac{1}{4}, 5 \frac{1}{2}, 3 \frac{1}{2}, 4 \frac{1}{2}$ og 4 år - i gennemsnit 6 år. 
at man i psykopatforvaringen har mulighed for at trænge dybere ned i de enkelte tilfælde og tilvejebringe grundlaget for en tidligere udskrivning, men i den eneste sag, der foreligger med dom til psykopatforvaring for et alvorligt drab, kom det til at betyde en tilbageholdelse i $12 \frac{1}{2}$ år.

Der er endvidere et tilfælde, hvor en 25-årig, ikke tidligere straffet person for drab af hustru blev id $\varnothing \mathrm{mt}$ straf af fængsel i 8 år. Ved dommen blev det antaget, at han på gerningstidspunktet havde befundet sig i en tilstand som beskrevet i straffelovens $\S 17$, men han blev fundet strafegnet. 2 år efter udtaler den til vedkommende statsfængsel knyttede psykiatriske konsulent, at fangen på grund af svære neurotiske afvigelser er uegnet til fortsat afsoning i statsfængsel, men har stærkt behov for behandling i en psykopatanstalt, og $\mathrm{i}$ medf $\phi \mathrm{r}$ af straffelovens $\S 17$, stk. $2, \mathrm{og}$ $\S 70$ blev det bestemt, at fuldbyrdelsen af fængselsstraffen på 8 år skulle afbrydes, og domfældte anbringes i forvaringsantalt for psykopater. Han sidder stadig i psykopatforvaringsanstalten, sk $\varnothing$ nt tidspunktet for hans ordinære pr $\phi$ vel $\phi$ sladelse efter straffe-
lovens $\S 38$, stk. 1, er passeret.

Dette kan måske vise, at anbringelse i psykopatforvaring ikke altid vil betyde hurtigere udskrivning.

Det er imidlertid heller ikke min mening, at alle farlige forbrydere, hvis delikt kvalificerer dem til livsvarigt fængsel, skal i
psykopatforvaring.

Min mening er, at domstolene koldt og lidenskabsløst og uden at skele til anstaltsapparatet skal afg $\phi r$ re, om tiltalte er en $\S 17$ mand, og er han det, skal det fremgå af dommen. Når det er afgjort, skal det afgøres, om han er egnet til straf, og her, mener jeg ikke, man kan sige, at livsvarigt fængsel ikke forudsætter, at den pågældende er påvirkelig af straf - dette må afgøres for livsvarigt fængsel på samme måde som ved tidsbestemt fængsel til og er der ikke noget særligt, der indicerer, at han er uegnet til straf, må der dømmes til livsvarigt fængsel. Dette vil som oftest være tilfældet, når det drejer sig om personer, der ikke tidligere har varet straffet, eller for hvem en tidligere strafafsoning er forl $\varnothing$ bet uden større komplikationer. At anvende livsvarigt fængsel overfor personer, der ved dommen er henført til $\S 17$, er også uden større betænkelighed, for domstolen véd, at der, når den har sørget for, at $\S 17$ er citeret, har ventilen i $\S 17$, stk. 2, hvorefter sagen på begæring af fængselsdirektøren kan indbringes for retten, hvis fortsættelse af straffen vil være unyttig eller vil medf $\varnothing$ re fare for alvorlig forværrelse af den d $\varnothing$ mtes tilstand, og så kan den pågældende på dette tidspunkt blive overført til psykopatforvaring. 